Article

\title{
Phthalates Exposure and Occupational Symptoms among Slovakian Hairdressing Apprentices
}

\author{
Branislav Kolena ${ }^{1, * \mathbb{D}}$, Ida Petrovicova ${ }^{1}$, Miroslava Sidlovska ${ }^{1}$, Henrieta Hlisnikova ${ }^{1}$, \\ Eliska Tomasovova ${ }^{1}$, Veronika Zoldakova ${ }^{1}$, Hana Trajtelova ${ }^{1}$, Lubomir Rybansky ${ }^{2}$, \\ Sona Wimmerova ${ }^{3}$ and Tomas Trnovec ${ }^{4}$ \\ 1 Department of Zoology and Anthropology, Constantine the Philosopher University in Nitra, \\ 94974 Nitra, Slovakia \\ 2 Department of Mathematics, Constantine the Philosopher University in Nitra, 94974 Nitra, Slovakia \\ 3 Institute of Biophysics, Informatics and Biostatistics, Slovak Medical University in Bratislava, \\ 83303 Bratislava, Slovakia \\ 4 Department of Environmental Medicine, Slovak Medical University in Bratislava, 83303 Bratislava, Slovakia \\ * Correspondence: bkolena@ukf.sk; Tel.: +421-37-6408-604
}

Received: 10 June 2019; Accepted: 12 August 2019; Published: 13 August 2019

check for updates

\begin{abstract}
The objectives of the study were to examine occupational exposure to phthalates of hairdressing apprentices from Slovakia ( $\mathrm{n}=74,89.2 \%$ females; $10.8 \%$ males), outcomes related to body composition and pulmonary functions. We used high-performance liquid chromatography and tandem mass spectrometry to the quantified urinary concentration of phthalates. Pulmonary function test (PFT), anthropometric measurements, and questionnaire were also conducted. We observed a decrease of $\%$ of predicted values of forced vital capacity (FVC $\%$ of PV) related exposure to mono(2-ethyl-5-oxohexyl) phthalate (MEOHP; $p=0.054$ ) and sum of bis(2-ethylhexyl) phthalate metabolites ( $\sum$ DEHP; $p=0.037$ ), and a decrease of $\%$ of predicted values of vital capacity (VC $\%$ of PV) related to exposure to MEOHP, $\sum$ DEHP $(p=0.008)$, and mono(2-ethyl-5-hydroxyhexyl) phthalate (MEHHP; $p=0.014$ ) in females. We detected associations between forced vital capacity (FVC) with weight $(p=0.002)$ and fat-free mass index (FFMI, $p=0.010)$. Vital capacity (VC) and VC $\%$ of PV increased with weight, body mass index (BMI), waist circumference (WC), hip circumference (HC), waist-hip ratio (WHR), the waist-height ratio (WHtR), fat mass index (FMI) and FFMI in females $(p \leq 0.014)$. Results of multivariate regression between PFT and anthropometric parameters adjusted to phthalates indicated exposure to MnBP and MEHP, changing body structure (BMI and FMI), subsequently affecting values of $\mathrm{FEV}_{1} / \mathrm{FVC}$.
\end{abstract}

Keywords: biomonitoring; phthalates; health; hairdressing apprentice; pulmonary function; occupational exposure

\section{Introduction}

Xenobiotic phthalates are industrially produced in huge quantities. Due to extensive use as plasticizers in numerous consumer products [1], phthalate esters (esters of phthalic acid) have become ubiquitous environmental contaminants [2]. Various routes of exposure to phthalates were observed depending on occupational and lifestyle habits and on sociodemographic factors such as diet [3-8], inhalation [9-12], and dermal contact [13] because of lack of their covalent binding in compounds [14]. Hairdressing is one of the most rapidly developing branches of the service industry in Europe which brings about new risks. Many hairdressers are lacking adequate knowledge on potential hazards of their occupation, as well as on preventive strategies for reducing them [15]. The main phthalates in cosmetics and personal care products are those of low molecular weight [16-18]. Phthalate 
esters were determined in five salons from the ten monitored in Taiwan by a walkthrough survey. Although concentrations of diester phthalates (dibutyl phthalate, diethyl phthalate, dimethyl phthalate, di[2-ethylhexyl] phthalate, and butyl benzyl phthalate) were below the occupational exposure limits, they were higher than what was found in general residential environments [19]. As a result, hairdressers are frequently occupationally exposed to phthalates contained in beauty products $[20,21]$. Health complications that affected various mucosal surfaces and oral and skin lesions, either independently or concurrently, have been significantly increased in the hairdressing apprentices [12,22-24]. Dysfunction of pulmonary, immune, and other systems [10,25-27] have been among various potential health impacts often ascribed to these exposures. The occupational environment of hairdressers has been found hazardous for the initiation of airway syndromes, varying from bronchial irritation to asthma [28] with a prevalence of 5\%-25\% [29-31]. Although most patients with occupational asthma are mature adults, there is evidence that the inflammation of airways started soon after early exposures in hairdressing apprenticeship [32,33]. Associations with other respiratory diseases and symptoms were also reported [12,34-40]. Concerning outcomes of such exposures, as a possible mechanistic link to airway diseases, the modulatory effects on peroxisome proliferation activated receptors (PPAR) have been suggested [2].

The aim of this study was to confirm and extend observations on phthalate exposure as a factor modulating human health. In a cross-sectional study, we monitored for phthalates urine of hairdresser apprentices and examined their respiratory functions with respect to inhalation exposures.

\section{Materials and Methods}

\subsection{Study Population}

We studied a pooled cohort of apprentices, aged 15-19 years $(n=74)$, attending vocational training schools for hairdressers, residing in districts of central Slovakia (Banska Bystrica and Zvolen). Hair treatments with similar hair products, equipment, and procedures were used in both districts. This meant that the scenarios of environmental exposures were most probably alike. The cohort consisted of 66 females $(89.19 \%)$ and 8 males $(10.81 \%)$. The study received approval from the Institutional Review Board of the Slovak Medical University and written informed consent was obtained from each participant. There was a possibility to withdraw participation anytime during the study. Subjects diagnosed with a respiratory illness or metabolic disorders and those with an incomplete questionnaire or with the prescription of bronchodilators or steroids were excluded.

\subsection{Anthropometry}

Anthropometric measurements were performed by a trained technician and repeated tests (three times and averaged) were conducted in agreement with the GPs (Gold Standard). Body composition (weight, body fat percentage, muscle mass percentage, and visceral fat level) was estimated by an Omron BF510 instrument (Kyoto, Japan). Body-mass index (BMI), waist-to-height ratio (WHtR), waist to hip ratio (WHR), fat mass indices (FMI), fat-free mass indices (FFMI) and a Body Shape Index (ABSI) were calculated.

\subsection{Spirometry}

Participants performed up to three maneuvers according to European Respiratory Society/ American Thoracic Society recommendations [41] and using a spirometer Spirolab II (MIR, Rome, Italy) and Winspiro PRO software, configured to individual preferences. Each subject was instructed and verbally encouraged to give maximal effort during the test. The percent predicted value was calculated as the percentage of the participant's measured value to the predicted value (\% of PV). The best result from three consecutive pulmonary function tests (PFTs) was taken for recording. The values obtained from the tests were: forced expiratory volume in $1 \mathrm{~s}$ (FEV1, L), forced vital capacity (FVC, L), Tiffeneau-Pinelli index - the ratio of FEV1 to FVC (FEV1/FVC, \%), peak expiratory flow (PEF), vital 
capacity (VC, L), and maximal voluntary ventilation (MVV, L). PFTs were conducted by a trained technician. The pack-year index $(\mathrm{p} / \mathrm{y})$ was calculated by multiplying the number of packs of cigarettes smoked per day by the number of years the person has smoked.

\subsection{Phthalate Analyses}

Hairdressing apprentices provided first spot urine samples $(2 \times 2 \mathrm{~mL})$ at the beginning of work, not earlier than 6:00 am, at the end of the workweek (Friday, work duration at least $8 \mathrm{~h}$ per shift), which gives information about individual exposures during last $24 \mathrm{~h}$. Samples were stored in a transport box at $2-6{ }^{\circ} \mathrm{C}$ and then in the deep freezer at $-73{ }^{\circ} \mathrm{C}$ until analysis. We used high-performance liquid chromatography (HPLC) and tandem mass spectrometry (MS/MS) (Infinity 1260 and 6410 triplequad, Agilent, Santa Clara, CA, USA) to quantified urinary concentration of compounds: MEP, MnBP, MEHP, MEHHP, MEOHP by the method of Pilka et al. [42]. The method was certificated for occupational/environmental medical—toxicological analysis for the Environmental medical field by EQUAS in German External Quality Assessment Scheme.

The analytical standards were purchased from Cambridge isotope laboratories (Tewksbury, MA, USA). Briefly, $1 \mathrm{ml}$ of urine was thawed, buffered with ammonium acetate, spiked with isotope-labeled phthalate standards, $\beta$-glucuronidase enzyme (K12 E. Coli, Roche, Mannheim, Germany) and incubated during $60 \mathrm{~min}$ at $37^{\circ} \mathrm{C}$. After deconjugation, samples were diluted with phosphate buffer $\left(\mathrm{NaH}_{2} \mathrm{PO}_{4}\right.$ in $\mathrm{H}_{3} \mathrm{PO}_{4}$ ) and loaded on SPE cartridges (ABS Elut Nexus, Agilent, Santa Clara, CA, USA). Cartridges were conditioned with acetonitrile followed by phosphate buffer before extraction. To remove the hydrophilic compound, SPE cartridges were flushed by formic acid (Merck KGaA, Darmstadt, Germany) and HPLC grade water. Elution of analytes was performed by acetonitrile (Merck KGaA, Darmstadt, Germany) and ethylacetate (Sigma-Aldrich, Steinheim, Germany). Eluate was dried by nitrogen gas and reconstituted with $200 \mu \mathrm{L}$ of $\mathrm{H}_{2} \mathrm{O}$ and acetonitrile (1:1). For HPLC, an Agilent Infinity 1260 liquid chromatography equipped with ZORBAX Eclipse phenyl-hexyl column $(2.1 \times 150 \mathrm{~mm}$, $3 \mu \mathrm{m})$ was used. The separation was done using a nonlinear gradient program of mobile phases $\mathrm{C}_{2} \mathrm{H}_{3} \mathrm{~N}$ and $0.1 \%$ acetic acid (Fisher Scientific, Loughborough, UK) in $\mathrm{H}_{2} \mathrm{O}$. For mass specific detection of phthalate metabolites we use triplequad with electro-spray ionization (Agilent 6410), according instrumental settings as follows: Spray ion voltage $(-3800 \mathrm{~V})$, nitrogen nebulizer gas pressure (8 psi), and nitrogen curtain gas pressure $(7 \mathrm{psi})$, capillary temperature $\left(430{ }^{\circ} \mathrm{C}\right)$, and collision gas (nitrogen) pressure (1.5 mTor). Chromatographic and mass spectrometric parameters are described in Table 1. The sum of the di(2-ethylhexyl) phthalate (DEHP) metabolites ( $\mathrm{MEHP}$ ) was calculated by adding the corresponding concentrations of MEHP, MEHHP, and MEOHP.

Table 1. Phthalate monoesters: Chromatographic and mass spectrometric parameters.

\begin{tabular}{ccccccc}
\hline Compound Name & $\begin{array}{c}\text { Precursor } \\
\text { Ion } \mathbf{( m / z )}\end{array}$ & $\begin{array}{c}\text { Product } \\
\text { Ion }(\mathbf{m} / \mathbf{z})\end{array}$ & F (V) & CE (V) & $\begin{array}{c}\text { RT } \\
(\mathbf{m i n})\end{array}$ & $\begin{array}{c}\text { LOD } \\
(\mathbf{n g} / \mathbf{m L})\end{array}$ \\
\hline MEP & 193 & 77.1 & 60 & 15 & 6.7 & 4.41 \\
MEP-labeled & 197.1 & 79 & 60 & 15 & 6.7 & \\
MnBP & 221.1 & 76.9 & 90 & 10 & 9.8 & 1.1 \\
MBP-labeled & 225.1 & 78.8 & 90 & 10 & 9.8 & \\
MEHP & 277.1 & 133.9 & 90 & 14 & 14.7 & 0.81 \\
MEHP-labeled & 281.1 & 137.1 & 90 & 14 & 14.7 & \\
MEHHP & 291 & 121.2 & 90 & 10 & 9.7 & 0.54 \\
MEHHP-labeled & 294.9 & 124 & 90 & 10 & 9.7 & \\
MEOHP & 293.1 & 121.2 & 95 & 12 & 9.7 & 0.64 \\
MEOHP-labeled & 297 & 124.1 & 95 & 12 & 9.7 & \\
\hline
\end{tabular}

MEP-monoethyl phthalate, MnBP-mono-n-butyl phthalate, MEHP-mono(2-ethylhexyl) phthalate, MEHHP-mono (2-ethyl-5-hydroxyhexyl) phthalate, MEOHP-mono(2-ethyl-5-oxohexyl) phthalate, F-fragmentor, CE-collision energy, RT-retention time (min), LOD-limit of detection $(\mathrm{ng} / \mathrm{mL})$. 


\subsection{Statistics}

Means with standard deviations (SDs), medians, and the 5th and 95th percentiles of concentrations were computed for the description of urinary phthalate metabolite levels. The non-parametric Mann-Whitney U (Wilcoxon rank-sum) test was used for analyses between pack-year index, sports activity, and dynamic pulmonary function. Multivariate regression analysis was used to estimate associations between pulmonary functions and anthropometric parameters (body weight, waist circumference-WC, hip circumference-HC, BMI, FMI, FFMI, WHR, WHtR, and ABSI) adjusted to occupational exposure to phthalates (monoethyl phthalate-MEP; mono-n-butyl phthalate-MnBP; mono(2-ethylhexyl) phthalate-MEHP; mono(2-ethyl-5-hydroxyhexyl) phthalate-MEHHP; mono(2-ethyl-5-oxohexyl) phthalate-MEOHP and sum bis(2-ethylhexyl) phthalate- $\sum$ DEHP). In these models, urinary phthalate concentrations were base 10 log-transformed. All statistical analyses were performed using the SPSS for Windows statistical package (version 14.0; SPSS Inc., Chicago, IL, USA).

\section{Results and Discussion}

The results of this study confirm and extend observations on health issues related to phthalate exposure in hairdressing apprentices, mentioned in our previous study focused on hairdressing occupational exposure [12] from Nitra and Levice region, Slovakia.

The baseline characteristics of the study group are shown in Table 2.

Table 2. Baseline characteristics of study group.

\begin{tabular}{|c|c|c|c|}
\hline \multicolumn{4}{|l|}{ Parameter } \\
\hline \multirow{3}{*}{\multicolumn{2}{|c|}{ Sex }} & Male & Female \\
\hline & & $8(10.8 \%)$ & $66(89.2 \%)$ \\
\hline & & \multicolumn{2}{|c|}{ Arithmetic Mean \pm SD } \\
\hline \multicolumn{2}{|c|}{ Age (years) } & $18 \pm 0.2$ & $17 \pm 0.2$ \\
\hline \multicolumn{2}{|c|}{ Body height $(\mathrm{cm})$} & $174 \pm 9$ & $164 \pm 6$ \\
\hline \multicolumn{2}{|c|}{ Body weight $(\mathrm{kg})$} & $66 \pm 16$ & $58 \pm 13$ \\
\hline \multicolumn{2}{|c|}{ ABSI } & $0.07 \pm 0.004$ & $0.07 \pm 0.007$ \\
\hline \multicolumn{2}{|c|}{ BMI } & $21 \pm 3$ & $23 \pm 4$ \\
\hline \multicolumn{2}{|c|}{ WHtR } & $0.4 \pm 0.05$ & $0.4 \pm 0.06$ \\
\hline \multicolumn{2}{|c|}{ WHR } & $0.8 \pm 0.06$ & $0.8 \pm 0.07$ \\
\hline \multicolumn{2}{|c|}{ FMI } & $3 \pm 2$ & $8 \pm 3$ \\
\hline \multicolumn{2}{|c|}{ FFMI } & $18 \pm 1$ & $15 \pm 1$ \\
\hline & & \multicolumn{2}{|c|}{ Count $(\%)$} \\
\hline \multirow[t]{2}{*}{ Residence } & rural & $2(2.7)$ & $35(47.3)$ \\
\hline & urban & $6(8.1)$ & $31(41.9)$ \\
\hline \multirow[t]{3}{*}{ Smoking } & smoker & $4(5.4)$ & $33(44.6)$ \\
\hline & ex-smoker & $2(2.7)$ & $3(4.1)$ \\
\hline & non-smoker & $2(2.7)$ & $30(40.5)$ \\
\hline \multirow[t]{4}{*}{ BMI } & $\leq 18$ & - & $2(2.7)$ \\
\hline & $18.5 \leq 25$ & $7(9.5)$ & $48(64.9)$ \\
\hline & $25 \leq 30$ & $1(1.4)$ & $9(12.2)$ \\
\hline & $\geq 30.1$ & - & $7(9.5)$ \\
\hline \multirow[t]{4}{*}{ WHtR } & $<0.40$ & $4(5.4)$ & $17(23.0)$ \\
\hline & $0.40-0.50$ & $4(5.4)$ & $39(52.7)$ \\
\hline & $0.51-0.56$ & - & $6(8.1)$ \\
\hline & $0.57-0.68$ & - & $4(5.4)$ \\
\hline \multirow[t]{2}{*}{ WHR } & underweight & $6(8.1)$ & $18(24.3)$ \\
\hline & normal & $2(2.7)$ & $38(51.4)$ \\
\hline
\end{tabular}


Table 2. Cont.

\begin{tabular}{cccc}
\hline Parameter & & & \\
\hline Sex & & Male & Female \\
\hline & overweight & - & $5(6.8)$ \\
& obesity & - & $5(6.8)$ \\
\hline \multirow{2}{*}{ FFMI } & low & $4(5.4)$ & $39(52.7)$ \\
& normal & $2(2.7)$ & $19(25.7)$ \\
& high & $2(2.7)$ & $8(10.8)$ \\
& very high & - & - \\
\hline FMI & low & $3(4.1)$ & $11(14.9)$ \\
& normal & $4(5.4)$ & $33(44.6)$ \\
& high & $1(1.4)$ & $14(18.9)$ \\
& very high & - & $8(10.8)$ \\
\hline
\end{tabular}

ABSI-A Body Shape Index, BMI-body-mass index, WHtR-waist-to-height ratio, WHR-waist-to-hip ratio, FFMI—fat free mass index, FMI—fat mass index.

Almost $89.2 \%$ of subjects declared their health status to be in very good condition. We documented self-rated perception of health problems as follows: Pneumonia (28.4\%), allergy (28.4\%), low blood pressure $(2.7 \%)$, asthma $(1.4 \%)$, hand eczema $(1.4 \%)$, epilepsy $(1.4 \%)$, high blood pressure $(1.4 \%)$, psoriasis $(1.4 \%)$, osteoporosis $(1.4 \%)$, and thyroid disease (1.4\%). Perceived self-rated general health problems in our cohort confirmed mucosal irritations and cardiovascular symptoms, in agreement with the findings of others $[12,34,35,43-45]$. We identified potential skin and mucous membrane irritation (sneezing - $24 \%$, itching $-12 \%$, cough $-7 \%$, breathlessness $-4 \%$ ), most often related to permanent waving $(45.9 \%)$ or use of hair spray $(17.6 \%)$. Similar symptoms were reported in studies from Turkey [46], Iran [47], and Slovakia [12]. In addition to these, in India, bleaching powders were rated as the most irritant chemicals that provoke respiratory symptoms in hairdressers [38].

Only $2.7 \%$ of probands used a personal protective mask; however, almost $84 \%$ of probands reported the use of personal protective gloves. Reported was the absence of air exhaust at the workplace or uncontrollable ventilation with open windows. The currently reported inadequate air exhausting at the workplace and non-using of professional personal protective equipment is in agreement with our previous observations [12] and those from Europe [31,34,48] and Africa [15] and Asia [49]. Improving the indoor air quality in hairdressing salons was also claimed in a study from Taiwan [19].

We did not observe an association between sports activity and pulmonary functions, body composition or phthalate exposure, despite frequently performed sports and physical activities, as stated by $83 \%$ of probands $(n=62$; running $-33.8 \%$, dancing $-24.3 \%$, volleyball $-16.2 \%$, football $-13.5 \%$ ). On the other hand, monitoring of lifestyle rendered negative findings, as $50 \%$ of probands were smokers $(\mathrm{n}=37 ; \mathrm{p} / \mathrm{y}=1.73 \pm 1.56 ; 44.6 \%$ of female and $5.4 \%$ of males) and $6.75 \%$ ex-smokers $(\mathrm{n}=5 ; \mathrm{p} / \mathrm{y}=1.29$ $\pm 0.86 ; 4.1 \%$ of females and $2.7 \%$ of males). It is in accordance with our previous data [12]. Females scored higher than men on the value of the pack-year index (1.86 \pm 1.63 compared to $1.74 \pm 1.38)$. Almost $83 \%$ of probands $(n=62)$ reported current exposure to environmental tobacco smoke (passive smoking) and half of the study population was exposed also in childhood, in agreement with studies worldwide [45,50-53].

Spirometry is common in primary care and an effective diagnostic test that provides information about the health status of the respiratory system. Almost $91 \%$ of probands reached $100 \%$ or even more than their VC\% of PV. On the other hand, in PEF and MVV tests, more than 50\% of probands scored less than $89.9 \%$ of predicted value (Table 3 ).

Peak values of FVC $\%$ of PV and MVV\% of PV were reached by non-smokers (Table 4). We conclude that in the studied population there are no differences probably due to the young age of probands. 
Table 3. Results of pulmonary function test (frequency of probands in PFT \% of PV).

\begin{tabular}{ccccccc}
\hline & FVC & FEV1 & PEF & VC & MVV & FEV1/FVC \\
\hline$\geq 100 \%$ & 64.06 & 76.56 & 20.31 & 90.63 & 14.06 & 68.75 \\
$\leq 99.9 \%$ & 35.94 & 23.44 & 79.69 & 9.37 & 85.94 & 31.25 \\
$\leq 89.9 \%$ & 15.63 & 12.5 & 60.94 & 3.13 & 59.37 & 3.13 \\
$\leq 79.9 \%$ & 3.13 & 4.69 & 28.13 & 1.56 & 31.25 & 1.56 \\
$\leq 69.9 \%$ & 1.56 & 1.56 & 10.94 & - & 10.94 & - \\
\hline
\end{tabular}

FVC $\%$ of PV, \% of predicted values of forced vital capacity; FEV1\% of PV, \% of predicted values of forced expiratory volume in $1 \mathrm{~s}$; $\mathrm{PEF} \%$ of $\mathrm{PV}, \%$ of predicted values of peak expiratory flow; $\mathrm{VC} \%$ of $\mathrm{PV}, \%$ of predicted values of vital capacity; $\mathrm{MVV} \%$ of $\mathrm{PV}, \%$ of predicted values of maximum voluntary ventilation; FEV1/FVC, ratio of forced expiratory volume in $1 \mathrm{~s}$ to forced vital capacity.

Table 4. Pulmonary function test (mean $\pm \mathrm{SD}$ ) in studied group affected by smoking habits.

\begin{tabular}{cccc}
\hline Parameter & Smokers & Ex-Smokers & No-Smokers \\
\hline & $\mathrm{n}=37$ & $\mathrm{n}=5$ & $\mathrm{n}=32$ \\
\hline FVC $\%$ of PV & $104 \pm 15$ & $105 \pm 9$ & $106 \pm 2$ \\
FEV1\% of PV & $108 \pm 14$ & $107 \pm 10$ & $108 \pm 2$ \\
FEV1/FVC & $88 \pm 6$ & $86 \pm 11$ & $87 \pm 1$ \\
PEF\% of PV & $86 \pm 16$ & $89 \pm 15$ & $87 \pm 2$ \\
VC\% of PV & $122 \pm 15$ & $127 \pm 10$ & $125 \pm 2$ \\
MVV\% of PV & $86 \pm 12$ & $83 \pm 8$ & $87 \pm 1$ \\
p/y index & $1.7 \pm 1.6$ & $1.3 \pm 0.9$ & - \\
\hline
\end{tabular}

FVC $\%$ of PV, \% of predicted values of forced vital capacity; FEV1\% of PV, \% of predicted values of forced expiratory volume in $1 \mathrm{~s} ; \mathrm{FEV} 1 / \mathrm{FVC}$, ratio of forced expiratory volume in $1 \mathrm{~s}$ to forced vital capacity; $\mathrm{PEF} \%$ of $\mathrm{PV}, \%$ of predicted values of peak expiratory flow; $\mathrm{VC} \%$ of $\mathrm{PV}, \%$ of predicted values of vital capacity; $\mathrm{MVV} \%$ of $\mathrm{PV}, \%$ of predicted values of maximum voluntary ventilation; $\mathrm{p} / \mathrm{y}$ index, pack year index.

Moreover, we detected symptoms of stage 1 of chronic obstructive pulmonary disease (COPD) [54] in $4.05 \%$ of females $(\mathrm{n}=3 ; \mathrm{p} / \mathrm{y}=1.40 \pm 2.43)$ and symptoms of simple and mucopurulent chronic bronchitis in $10.8 \%$ of subjects ( $\mathrm{n}=8 ; 1$ male, 7 females; $\mathrm{p} / \mathrm{y}=1.10 \pm 1.58)$. In probands with smoking history (current smokers and ex-smokers), we detected an association between a pack-year index and $\operatorname{PEF}(p=0.002, \alpha=0.01)$ (Mann-Whitney U test).

Vital capacity is the lung volume that can be measured as slow vital capacity (VC) or forced vital capacity (FVC). In normal subjects, there is little or no difference between VC and FVC [55]. In our cohort, VC\% of PV reached higher values than FVC\% of PV in both genders $(126.49 \%$ vs. $106.83 \%$ in males; $124.49 \%$ vs. $105.59 \%$ in females). It follows from some studies [56,57] that FVC is smaller than VC both in asthma patients and COPD patients because of airflow limitation, small airway collapse, and gas trapping. The increasing gap between VC\% of PV and FVC\% of PV from asymptomatic probands through those diagnosed from such as simple and mucopurulent chronic bronchitis to probands with COPD symptoms indicates that those findings could be affected by exposure to chemical substances in our study population.

We observed the significant positive association (Pearson) between results of PFTs, either as absolute values or percent of predicted values, and anthropometric parameters, in the female cohort (Table 5).

As expected, most statistically significant relationships were with absolute values, however many remained significant even when expressed as a percent of predicted values as follows: With weight $(p=0.008)$, BMI $(p=0.005)$, WC $(p=0.003)$, WHR $(p=0.005)$, WhTR $(p=0.003)$, FMI $(p=0.009)$, and FFMI $(p=0.003)$. We observed such behavior mostly with parameters related to VC. We also observed an association between FVC and weight $(p=0.002)$ and FFMI $(0.01)$. 
Table 5. Bivariate analysis between PFT parameters and anthropometric parameters in females $(\mathrm{n}=66)$, Pearson correlation coefficient $(p$ value).

\begin{tabular}{|c|c|c|c|c|c|c|c|c|c|c|}
\hline \multirow{2}{*}{$\begin{array}{c}\text { Anthropometric } \\
\text { Parameters }\end{array}$} & \multicolumn{10}{|c|}{ Pulmonary Function Tests } \\
\hline & FVC & $\%$ FVC of PV & VC & $\%$ VC of PV & PEF & $\%$ PEF of PV & FEV1/FVC & $\begin{array}{c}\% \text { FEV1/FVC of } \\
\text { PV }\end{array}$ & MVV & $\%$ MVV of PV \\
\hline Weight & $0.403(0.002)$ & $0.081(0.552)$ & $0.595(<0.001)$ & $0.353(0.008)$ & $0.310(0.020)$ & $0.064(0.642)$ & $-0.213(0.116)$ & $-0.180(0.184)$ & $0.122(0.370)$ & $-0.138(0.310)$ \\
\hline BMI & $0.224(0.097)$ & $0.049(0.721)$ & $0.469(<0.001)$ & $0.367(0.005)$ & $0.191(0.159)$ & $0.064(0.640)$ & $-0.245(0.069)$ & $-0.229(0.090)$ & $-0.008(0.951)$ & $-0.138(0.311)$ \\
\hline ABSI & $0.150(0.270)$ & $-0.038(0.781)$ & $-0.042(0.759)$ & $0.070(0.609)$ & $-0.062(0.648)$ & $0.027(0.842)$ & $0.072(0.600)$ & $0.060(0.660)$ & $0.145(0.286)$ & $0.243(0.071)$ \\
\hline Waist circumference & $0.184(0.175)$ & $0.052(0.704)$ & $0.457(<0.001)$ & $0.393(0.003)$ & $0.172(0.204)$ & $0.074(0.558)$ & $-0.178(0.190)$ & $-0.166(0.222)$ & $0.147(0.280)$ & $0.048(0.723)$ \\
\hline Hip circumference & $0.230(0.088)$ & $-0.004(0.977)$ & $0.410(0.002)$ & $0.243(0.070)$ & $0.216(0.110)$ & $0.046(0.734)$ & $-0.136(0.318)$ & $-0.106(0.436)$ & $0.085(0.533)$ & $-0.090(0.510)$ \\
\hline WHR & $0.094(0.484)$ & $0.097(0.478)$ & $0.326(0.014)$ & $0.368(0.005)$ & $0.053(0.696)$ & $0.048(0.727)$ & $-0.170(0.211)$ & $-0.176(0.195)$ & $0.128(0.348)$ & $0.127(0.350)$ \\
\hline WHTR & $0.052(0.706)$ & $0.038(0.781)$ & $0.349(0.008)$ & $-0.393(0.003)$ & $0.082(0.547)$ & $0.079(0.565)$ & $-0.204(0.131)$ & $-0.205(0.130)$ & $0.060(0.660)$ & $0.065(0.635)$ \\
\hline FMI & $0.174(0.199)$ & $0.017(0.902)$ & $0.431(0.001)$ & $0.344(0.009)$ & $0.141(0.300)$ & $0.028(0.836)$ & $-0.253(0.060)$ & $-0.237(0.079)$ & $-0.045(0.744)$ & $-0.157(0.249)$ \\
\hline FFMI & $0.342(0.010)$ & $0.141(0.301)$ & $0.526(<0.001)$ & $0.392(0.003)$ & $0.304(0.023)$ & $0.154(0.257)$ & $-0.203(0.134)$ & $-0.187(0.167)$ & $0.097(0.476)$ & $-0.064(0.637)$ \\
\hline
\end{tabular}

PFT-Pulmonary Function Test; FEV1—forced expiratory volume in 1 s (L); FVC-forced vital capacity (L); FEV1/FVC- the ratio of FEV1 to FVC (\%); PEF-peak expiratory flow; VC-vital capacity (L); MVV—-maximal voluntary ventilation (L); FVC\% of PV— $\%$ of predicted values of forced vital capacity; FEV1\% of PV— $\%$ of predicted values of forced expiratory volume in $1 \mathrm{~s} ; \mathrm{PEF} \%$ of PV— $\%$ of predicted values of peak expiratory flow; VC\% of PV—\% of predicted values of vital capacity; MVV\% of PV- $\%$ of predicted values of maximum voluntary ventilation; ABSI—A Body Shape Index, BMI—body-mass index, WHtR—waist-to-height ratio, WHR—waist-to-hip ratio, FFMI—fat free mass index, FMI—fat mass index. 
We included in our measures ABSI, as body shape measured by ABSI, derivable from basic clinical measurements, appears to be a substantial risk factor for premature mortality in the general population. In our study ABSI reached higher values in females than in males (0.0726 vs. 0.0709; ABSI Z-Score $=-1.3$ vs. -1.7 ; ABSI percent $=14$ vs. 7 ). On the other hand, the relative risk estimated from ABSI was the same for both sexes and reached 0.7 (range 0.6-0.9). It means that males and females had a 30 percent lower risk of death rate ( 1 represents average risk; the range is the approximate $95 \%$ confidence interval).

We compared the current results with our previous data on hairdressing apprentices [12] to verify the exposure mode and expand data on this specific type of educational and occupational environment. We detected higher FEV1\% of PV $(p \leq 0.001)$ and VC $(p \leq 0.001)$ in control group of our previous study [12] in comparison with hairdressing apprentices from the current study, and FVC \% of PV $(p \leq 0.05), \operatorname{FEV} 1(p \leq 0.001)$, and VC $(p \leq 0.001)$ in comparison with hairdressing apprentices from our previous study [12]. Our findings on PFT, (except PEF), are in accordance with results from cohort composed from Parisian hairdressing apprentices [50]. However, compared to other hairdressing occupational studies $[47,49,58]$ we detected higher values of pulmonary functions. These differences, however, may have been influenced by age and length of exposure, as in the current study we examined apprentices and not adult hairdressers.

From all probands $(n=74)$ only $64(86.49 \%)$ provided a first-morning-void urine sample. Analyses detected MEHHP, MEP, and MnBP in all urine samples, followed by MEOHP (98.4\%) and MEHP $(89.16 \%)$. The frequency distribution of the concentration of urinary phthalate metabolites was positively skewed. Urinary concentration of phthalate monoesters confirmed occupational exposure to phthalates shown in Table 6.

Table 6. Descriptive statistics of concentrations of phthalate metabolites $(\mathrm{ng} / \mathrm{mL})$ in study group $(\mathrm{n}=74)$.

\begin{tabular}{cccccccc}
\hline & \multirow{2}{*}{ Mean } & \multirow{2}{*}{ SD } & \multirow{2}{*}{ Min } & \multicolumn{3}{c}{ Percentiles } & \multirow{2}{*}{ Max } \\
\cline { 5 - 7 } & & & & 5th & 50th & 95th & \\
\hline MEP & 330 & 837 & 2.21 & 24 & 108 & 884 & 5761.47 \\
MnBP & 130 & 98 & 12.04 & 24 & 109 & 338 & 482.33 \\
MEHP & 7.5 & 9.3 & 0.81 & $\leq$ LOD & 4.2 & 30 & 48.42 \\
MEHHP & 38 & 33 & 5.4 & 7 & 27 & 97 & 173.47 \\
MEOHP & 20 & 18 & 0.3 & 2.09 & 14 & 52 & 86.61 \\
LDEHP & 65 & 57 & 6.5 & 11 & 45 & 158 & 267.78 \\
\hline
\end{tabular}

MEP-monoethyl phthalate, MnBP-mono-n-butyl phthalate, MEHP-mono(2-ethylhexyl) phthalate, MEHHP-mono(2-ethyl-5-hydroxyhexyl) phthalate, MEOHP-mono(2-ethyl-5-oxohexyl) phthalate, $\sum$ DEHP = sum of MEHP, MEHHP, MEOHP, LOD-Limit of detection.

The highest ratio level from DEHP metabolites scored MEHHP (57.24\%), followed by MEOHP (31.29\%) and MEHP (11.46\%). The mean excretion-ratios of MEHP to MEHHP and MEHP to MEOHP were 1:5 and 1:2.7, respectively. Basically, the excretion pattern of primary and secondary DEHP metabolites was in accordance with that observed in hairdressing apprentices previously [12]; however, currently we observed higher concentration of all phthalate metabolites (medians and 95 percentile, $\mathrm{ng} / \mathrm{mL}$ ), except 95 percentile of MEHHP and $\sum$ DEHP in comparison to our previous data. Concentrations of MEHHP ( $p \leq 0.005), \operatorname{MEOHP}(p \leq 0.005)$, and $\sum \mathrm{DEHP}(p \leq 0.05)$ were higher in the current study compared to urine samples of hairdressing apprentices from Slovakia [12]. Those finding suggest potential higher exposure to parental diesters in this specific type of work environment.

The present median concentration of MEP compares well with US data on nail salon workers (22-58 years), although we scored higher with MEHHP and MEOHP but lower with MEHP [59]. However, in children exposed to vinyl flooring at home, median and 95 percentile of MEP concentration reached higher values than in our study. 
We also observed a decrease of FVC $\%$ of PV vs. MEOHP ( $\mathrm{r}=-0.26 ; p=0.054)$ and $\sum$ DEHP $(\mathrm{r}=-0.28, p=0.037)$ and of VC $\%$ of PV vs. MEHHP $(\mathrm{r}=-0.33, p=0.014), \operatorname{MEOHP}(\mathrm{r}=-0.35, p=0.008)$ and $\sum$ DEHP $(r=-0.35, p=0.008)$ in females (Table 7).

In males $(\mathrm{n}=8)$ we observed negative associations between MnBP and waist circumference $(\mathrm{r}=$ $-0.74, p \leq 0.05)$, hip circumference $(\mathrm{r}=-0.86, p \leq 0.05)$, and WHtR $(\mathrm{r}=-0.74, p \leq 0.05)$ and between MEP and FVC $\%$ of PV $(r=-0.88, p \leq 0.05)$. In contrast, we observed a positive association between the concentration of MEHP and MVV $\%$ of PV $(r=0.74, p \leq 0.05)$. Our data do not confirm the hypothesis about the obesogenic effects of phthalates [60]. On the other hand, associations between phthalates exposure and fat distribution and accumulation could be sex-specific [61]. This hypothesis must be confirmed on a larger cohort.

Next, we examined, using multivariate regression analysis, how exposure to phthalates may affect the relationship between anthropometric parameters and the PFTs in hairdressing female apprentices. In Table 8, we show statistically significant results of bivariate and multivariate regression tests. An adjustment to phthalate exposure did not influence the association between absolute or predicted values of PFTs and anthropometric parameters. The FEV1/FVC, in contrast, was not related to anthropometric parameters; however, after adjustment to MnBP a significant association between FEV1/FVC and BMI and FMI appeared $(\mathrm{r}=-0.484, p \leq 0.041 ; \mathrm{r}=-0.657, p \leq 0.036$, respectively), and after adjustment for MEHP, the FEV1/FVC was related to FMI $(r=-0.604, p \leq 0.047)$.

It deserves a note that we have observed higher concentration of phthalates in the subgroup of probands with COPD symptoms providing urine sample $(n=2)$ compared to the asymptomatic ones as follows: MEP (263.80 ng/mL vs. $98.87 \mathrm{ng} / \mathrm{mL}), \operatorname{MnBP}(179.06 \mathrm{ng} / \mathrm{mL}$ vs. $164.91 \mathrm{ng} / \mathrm{mL})$, MEHP ( $8.56 \mathrm{ng} / \mathrm{mL}$ vs. $4.02 \mathrm{ng} / \mathrm{mL})$, MEHHP (54.02 ng/mL vs. $27.09 \mathrm{ng} / \mathrm{mL})$, MEOHP (31.32 ng/mL vs. $14.97 \mathrm{ng} / \mathrm{mL}$ ), and $\sum$ DEHP (93.90 ng/mL vs. $45.35 \mathrm{ng} / \mathrm{mL}$ ). Despite the low incidence of symptoms of simple and mucopurulent chronic bronchitis and COPD symptoms in our study $(10.8 \%$ and $4.05 \%$, respectively), progress and deterioration of this condition, in connection with phthalates overexposure, can be expected in the future. Namely, smoking combined with exposure to a mixture of chemicals at the workplace could be a potential risk factor for the development of these entities. Further study is needed to explore this hypothesis.

We hypothesize that occupational exposure to phthalates causes changes in body constitution which secondarily can affect pulmonary functions.

Limitations of our study are due to the lack of environmental air data confirming exposures by monitoring the spot urine measures of phthalates. Moreover, non-monitored chemicals used in the workplace could play a role as co-exposure. Moreover, life habits and consumer practices of probands could affect concentrations of phthalates. The mixture effects of all pollutants representing occupational exposure have to be accounted for. A limitation of the study was also the relatively small sample size. For this reason, our results cannot be generalized to the broader community based on this study alone. 
Table 7. Bivariate analysis between PFT parameters and phthalate metabolites in females $(\mathrm{n}=66)$, Spearman correlation coefficient $(p$ value).

\begin{tabular}{|c|c|c|c|c|c|c|c|c|c|c|}
\hline \multirow{2}{*}{$\begin{array}{l}\text { Phthalate } \\
\text { Metabolites }\end{array}$} & \multicolumn{10}{|c|}{ Pulmonary Function Tests } \\
\hline & FVC & $\%$ FVC of PV & vC & $\%$ VC of PV & PEF & $\%$ PEF of PV & FEV1/FVC & $\begin{array}{c}\% \text { FEV1/FVC of } \\
\text { PV }\end{array}$ & MVV & $\%$ MVV of PV \\
\hline MEHHP & $-0.125(0.360)$ & $-0.253(0.060)$ & $-0.204(0.132)$ & $-0.328(0.014)$ & $0.095(0.487)$ & $0.049(0.718)$ & $0.162(0.233)$ & $0.170(0.221)$ & $-0.136(0.319)$ & $-0.169(0.212)$ \\
\hline MEOHP & $-0.173(0.203)$ & $-0.259(0.054)$ & $-0.251(0.062)$ & $-0.351(0.008)$ & $0.064(0.637)$ & $0.037(0.784)$ & $0.206(0.128)$ & $0.209(0.123)$ & $-0.094(0.490)$ & $-0.103(0.451)$ \\
\hline MEHP & $-0.148(0.277)$ & $-0.190(0.161)$ & $-0.159(0.243)$ & $-0.216(0.110)$ & $-0.051(0.708)$ & $-0.055(0.689)$ & $0.088(0.518)$ & $0.096(0.480)$ & $-0.058(0.673)$ & $-0.004(0.978)$ \\
\hline$\sum$ DEHP & $-0.161(0.237)$ & $-0.279(0.037)$ & $-0.229(0.090)$ & $-0.354(0.008)$ & $0.046(0.737)$ & $0.008(0.952)$ & $0.171(0.207)$ & $0.178(0.191)$ & $-0.119(0.381)$ & $-0.136(0.317)$ \\
\hline $\mathrm{MnBP}$ & $0.035(0.796)$ & $0.020(0.885)$ & $-0.064(0.638)$ & $-0.090(0.512)$ & $0.117(0.391)$ & $0.096(0.480)$ & $0.118(0.385)$ & $0.112(0.412)$ & $-0.107(0.432)$ & $-0.125(0.359)$ \\
\hline MEP & $0.010(0.945)$ & $0.033(0.808)$ & $0.170(0.210)$ & $0.239(0.076)$ & $-0.001(0.995)$ & $-0.006(0.967)$ & $-0.064(0.637)$ & $-0.058(0.670)$ & $0.010(0.944)$ & $0.033(0.811)$ \\
\hline
\end{tabular}

FEV1—forced expiratory volume in $1 \mathrm{~s}$ (L); FVC—forced vital capacity (L); FEV1/FVC—-the ratio of FEV1 to FVC (\%); PEF—peak expiratory flow; VC—vital capacity (L); MVV—-maximal voluntary ventilation (L); FVC\% of PV— $\%$ of predicted values of forced vital capacity; FEV1 \% of PV- $\%$ of predicted values of forced expiratory volume in $1 \mathrm{~s}$; PEF\% of PV- $\%$ of predicted values of peak expiratory flow; $\mathrm{VC} \%$ of $\mathrm{PV}-\%$ of predicted values of vital capacity; MVV\% of PV-\% of predicted values of maximum voluntary ventilation; MEHHP-mono(2-ethyl-5-hydroxyhexyl) phthalate; MEOHP-mono(2-ethyl-5-oxohexyl) phthalate; MEHP—mono(2-ethylhexyl) phthalate (MEHP); $\sum$ DEHP—sum of MEHP, MEOHP, and MEHHP; MnBP-mono-n-butyl phthalate; MEP-monoethyl phthalate.

Table 8. A multivariate regression analysis between pulmonary functional test parameters and anthropometric parameters adjusted to occupational exposure to phthalates in females.

\section{PHTHALATE METABOLITES}

\begin{tabular}{|c|c|c|c|c|c|c|c|c|c|c|c|c|c|c|c|}
\hline \multirow[b]{3}{*}{ PFT } & \multirow[b]{3}{*}{ ANTHROPOMETRY } & \multicolumn{2}{|c|}{ A } & \multicolumn{12}{|c|}{ B } \\
\hline & & \multirow[b]{2}{*}{ B } & \multirow[b]{2}{*}{$p$} & \multicolumn{2}{|c|}{ МЕHНP } & \multicolumn{2}{|c|}{ МЕОНР } & \multicolumn{2}{|c|}{ MEHP } & \multicolumn{2}{|c|}{$\sum$ DEHP } & \multicolumn{2}{|c|}{ MnBP } & \multicolumn{2}{|c|}{ MEP } \\
\hline & & & & $B$ & $p$ & $B$ & $p$ & B & $p$ & B & $p$ & B & $p$ & B & $p$ \\
\hline \multirow{2}{*}{ FVC } & weight & 0.018 & 0.002 & 0.018 & 0.002 & 0.018 & 0.002 & 0.018 & 0.003 & 0.018 & 0.002 & 0.019 & 0.002 & 0.018 & 0.003 \\
\hline & FFMI & 0.175 & 0.01 & 0.172 & 0.011 & 0.17 & 0.012 & 0.171 & 0.012 & 0.171 & 0.012 & 0.182 & 0.01 & 0.171 & 0.013 \\
\hline FVC $\%$ of PV & ABSI & 4.857 & 0.051 & -5.225 & 0.051 & -3.804 & 0.072 & -3.424 & 0.069 & -5.251 & 0.041 & & & & \\
\hline \multirow{8}{*}{$\mathrm{VC}$} & weight & 0.035 & $<0.001$ & 0.035 & $<0.001$ & 0.035 & $<0.001$ & 0.035 & $<0.001$ & 0.035 & $<0.001$ & 0.037 & $<0.001$ & 0.033 & $<0.001$ \\
\hline & BMI & 0.087 & $<0.001$ & 0.087 & $<0.001$ & 0.086 & $<0.001$ & 0.087 & $<0.001$ & 0.087 & $<0.001$ & 0.093 & $<0.001$ & 0.081 & 0.001 \\
\hline & waist circumference & 0.036 & $<0.001$ & 0.035 & 0.001 & 0.035 & 0.001 & 0.035 & 0.001 & 0.035 & 0.001 & 0.036 & $<0.001$ & 0.033 & 0.001 \\
\hline & hip circumference & 0.043 & 0.002 & 0.042 & 0.002 & 0.041 & 0.002 & 0.042 & 0.002 & 0.042 & 0.002 & 0.044 & 0.002 & 0.040 & 0.003 \\
\hline & WHR & 3.655 & 0.014 & 3.473 & 0.024 & 3.409 & 0.027 & 3.491 & 0.023 & 3.435 & 0.026 & 3.675 & 0.015 & 3.248 & 0.028 \\
\hline & WHtR & 4.803 & 0.008 & 4.608 & 0.013 & 4.527 & 0.015 & 4.61 & 0.013 & 4.563 & 0.014 & 4.829 & 0.009 & 4.267 & 0.019 \\
\hline & FMI & 0.106 & 0.001 & 0.106 & 0.001 & 0.105 & 0.001 & 0.107 & 0.001 & 0.105 & 0.001 & 0.113 & 0.001 & 0.096 & 0.003 \\
\hline & FFMI & 0.356 & $<0.001$ & 0.353 & $<0.001$ & 0.350 & $<0.001$ & 0.353 & $<0.001$ & 0.351 & $<0.001$ & 0.376 & $<0.001$ & 0.339 & $<0.001$ \\
\hline
\end{tabular}


Table 8. Cont.

PHTHALATE METABOLITES

\begin{tabular}{|c|c|c|c|c|c|c|c|c|c|c|c|c|c|c|c|}
\hline \multirow[b]{4}{*}{ PFT } & \multirow[b]{4}{*}{ ANTHROPOMETRY } & & & \multicolumn{12}{|c|}{ PHTHALATE METABOLITES } \\
\hline & & \multicolumn{2}{|c|}{ A } & \multicolumn{12}{|c|}{ B } \\
\hline & & \multirow[b]{2}{*}{$\mathbf{B}$} & \multirow[b]{2}{*}{$p$} & \multicolumn{2}{|c|}{ МЕHНP } & \multicolumn{2}{|c|}{ МЕOHP } & \multicolumn{2}{|c|}{ МЕHP } & \multicolumn{2}{|c|}{$\sum \mathrm{DEHP}$} & \multicolumn{2}{|c|}{ MnBP } & \multicolumn{2}{|c|}{ MEP } \\
\hline & & & & B & $p$ & B & $p$ & В & $p$ & ß & $p$ & В & $p$ & B & $p$ \\
\hline \multirow{7}{*}{ VC\% of PV } & weight & 0.537 & 0.008 & 0.532 & 0.007 & 0.52 & 0.009 & 0.523 & 0.009 & 0.526 & 0.008 & 0.565 & 0.007 & 0.485 & 0.017 \\
\hline & BMI & 1.763 & 0.005 & 1.744 & 0.005 & 1.712 & 0.006 & 1.748 & 0.006 & 1.732 & 0.005 & 1.898 & 0.004 & 1.605 & 0.012 \\
\hline & waist circumference & 0.795 & 0.003 & 0.738 & 0.005 & 0.725 & 0.007 & 0.748 & 0.005 & 0.726 & 0.006 & 0.799 & 0.003 & 0.728 & 0.007 \\
\hline & WHR & 106.72 & 0.005 & 96.02 & 0.013 & 95.52 & 0.014 & 101.1 & 0.010 & 94.55 & 0.015 & 107.1 & 0.006 & 98.126 & 0.010 \\
\hline & WHTR & 139.85 & 0.003 & 129.7 & 0.005 & 127.6 & 0.007 & 131.9 & 0.005 & 127.7 & 0.006 & 141.1 & 0.003 & 128.74 & 0.006 \\
\hline & FMI & 2.19 & 0.009 & 2.17 & 0.009 & 2.131 & 0.010 & 2.189 & 0.009 & 2.161 & 0.009 & 2.351 & 0.008 & 1.96 & 0.021 \\
\hline & FFMI & 6.865 & 0.003 & 6.729 & 0.003 & 6.619 & 0.003 & 6.755 & 0.003 & 6.641 & 0.003 & 7.291 & 0.002 & 6.465 & 0.005 \\
\hline \multirow{2}{*}{ FEV1/FVC } & BMI & -0.415 & 0.069 & -0.412 & 0.072 & -0.409 & 0.075 & -0.434 & 0.058 & -0.411 & 0.073 & -0.484 & 0.041 & -0.415 & 0.077 \\
\hline & FMI & -0.566 & 0.060 & -0.563 & 0.063 & -0.559 & 0.065 & -0.604 & 0.047 & -0.563 & 0.063 & -0.657 & 0.036 & -0.57 & 0.067 \\
\hline
\end{tabular}

A-Univariate regression; B-Multivariate regression; PFT—Pulmonary Function Test; FVC—forced vital capacity (L); FVC \% of PV— $\%$ of predicted values of forced vital capacity; VC-vital capacity (L); VC\% of PV—\% of predicted values of vital capacity; FEV1/FVC—-the ratio of FEV1 to FVC (\%); ABSI—A Body Shape Index, BMI—body-mass index, WHtR - waist-to-height ratio, WHR - waist-to-hip ratio, FFMI—fat free mass index, FMI—fat mass index, MEHHP-mono(2-ethyl-5-hydroxyhexyl) phthalate; MEOHP-mono(2-ethyl-5-oxohexyl) phthalate; MEHP—mono(2-ethylhexyl) phthalate (MEHP); $\sum$ DEHP—sum of MEHP, MEOHP, and MEHHP; MnBP—mono-n-butyl phthalate; MEP—-monoethyl phthalate 


\section{Conclusions}

Data indicate that hairdressing-related phthalate exposure is significant. We observed an association between pulmonary function test and anthropometric parameters adjusted to occupational exposure to phthalates. We hypothesize that exposure to phthalates during adolescence affects body composition which secondarily could affect the values of the pulmonary function of females' hairdressing apprentices.

We can conclude that biomonitoring of phthalates in this type of occupational environment is needed to regulate the harmful effect on health. Adequate attention should be given to education about potential hazards and preventive strategies in this occupational environment. Appropriate preventive strategy by pulmonary function test in periodical monitoring can detect early signs of pulmonary dysfunctions.

Exposure to phthalates and other chemicals in hairdresser salons means that the health of the general population when receiving hair salon services can be also endangered. To prevent these unnecessary exposures, improving indoor air quality in this type of work environment is needed. We recommended mandatory local exhaust ventilation and education on the use of personal protective equipment worn by workers to protect against hazards in the environment.

Author Contributions: Conceptualization, B.K. and I.P.; Data curation, B.K.; Formal analysis, M.S., H.H., L.R., and S.W.; Investigation, B.K., I.P., E.T., V.Z., H.T., and T.T.; Methodology, B.K. and M.S.; Project administration, I.P.; Resources, M.S.; Software, S.W.; Supervision, T.T.; Writing-Original draft, B.K.

Funding: This research was supported by Project of Ministry of Health of SR no. 2016/9-UKFN-1.

Acknowledgments: We thank Michaela Földešiová for excellent technical assistance.

Conflicts of Interest: The authors declare no conflict of interest. The funders had no role in the design of the study; in the collection, analyses, or interpretation of data; in the writing of the manuscript, or in the decision to publish the results.

\section{References}

1. Koch, H.M.; Angerer, J. Phthalates: Biomarkers and Human Biomonitoring. In Biomarkers and Human Biomonitoring; Knudsen, L.E., Hundebøll, N., Merlo, D.F., Eds.; RSC Publishing: Cambridge, UK, 2012; Volume 1, pp. 179-233.

2. Kocbach Bølling, A.; Holme, J.A.; Bornehag, C.G.; Nygaard, U.C.; Bertelsen, R.J.; Nånberg, E.; Bodin, J.; Sakhi, A.K.; Thomsen, C.; Becher, R. Pulmonary phthalate exposure and asthma-Is PPAR a plausible mechanistic link? EXCLI J. 2013, 12, 733-759. [PubMed]

3. Rudel, R.A.; Gray, J.M.; Engel, C.L.; Rawsthorne, T.W.; Dodson, R.E.; Ackerman, J.M.; Rizzo, J.; Nudelman, J.L.; Brody, J.G. Food packaging and bisphenol A and bis(2-ethyhexyl) phthalate exposure: Findings from a dietary intervention. Environ. Health Perspect. 2011, 119, 914-920. [CrossRef] [PubMed]

4. Koch, H.M.; Lorber, M.; Christensen, K.L.; Pälmke, C.; Koslitz, S.; Brüning, T. Identifying sources of phthalate exposure with human biomonitoring: Results of a $48 \mathrm{~h}$ fasting study with urine collection and personal activity patterns. Int. J. Hyg. Environ. Health 2013, 216, 672-681. [CrossRef] [PubMed]

5. Whyatt, R.M.; Perzanowski, M.S.; Just, A.C.; Rundle, A.G.; Donohue, K.M.; Calafat, A.M.; Hoepner, L.A.; Perera, F.P.; Miller, R.L. Asthma in inner-city children at 5-11 years of age and prenatal exposure to phthalates: The Columbia Center for Children's Environmental Health Cohort. Environ. Health Perspect. 2014, 122, 1141-1146. [CrossRef] [PubMed]

6. Petrovičová, I.; Kolena, B.; Šidlovská, M.; Pilka, T.; Wimmerová, S.; Trnovec, T. Occupational exposure to phthalates in relation to gender, consumer practices and body composition. Environ. Sci. Pollut. Res. Int. 2016, 23, 24125-24134. [CrossRef] [PubMed]

7. Šidlovská, M.; Petrovičová, I.; Kolena, B.; Pilka, T.; Šovčíková, E.; Trnovec, T. Exposure of children to phthalates and the impact of consumer practices in Slovakia. Rev. Environ. Health 2017, 32, 211-214. [CrossRef] [PubMed] 
8. Hlisníková, H.; Šidlovská, M.; Kolena, B.; Petrovičová, I. Association between consumer practices and phthalate exposure in children and their parents from Slovakia. Pol. J. Environ. Stud. 2019, 28, 1195-1202. [CrossRef]

9. Kolarik, B.; Naydenov, K.; Larsson, M.; Bornehag, C.G.; Sundell, J. The association between phthalates in dust and allergic diseases among Bulgarian children. Environ. Health Perspect. 2008, 116, 98-103. [CrossRef] [PubMed]

10. Dodson, R.E.; Nishioka, M.; Standley, L.J.; Perovich, L.J.; Brody, J.G.; Rudel, R.A. Endocrine disruptors and asthma-associated chemicals in consumer products. Environ. Health Perspect. 2012, 120, 935-943. [CrossRef] [PubMed]

11. Just, A.C.; Miller, R.L.; Perzanowski, M.S.; Rundle, A.G.; Chen, Q.; Jung, K.H.; Hoepner, L.; Camann, D.E.; Calafat, A.M.; Perera, F.P.; et al. Vinyl flooring in the home is associated with children's airborne butylbenzyl phthalate and urinary metabolite concentrations. J. Expo. Sci. Environ. Epidemiol. 2015, 25, 574-579. [CrossRef] [PubMed]

12. Kolena, B.; Petrovičová, I.; Šidlovská, M.; Pilka, T.; Neuschlová, M.; Valentová, I.; Rybanský, L.; Trnovec, T. Occupational phthalate exposure and health outcomes among hairdressing apprentices. Hum. Exp. Toxicol. 2017, 36, 1100-1112. [CrossRef] [PubMed]

13. Li, J.; Li, L.; Zuo, H.; Ke, C.; Yan, B.; Wen, H.; Zhang, Y.; Yang, X. T-helper type-2 contact hypersensitivity of Balb/c mice aggravated by dibutyl phthalate via long-term dermal exposure. PLoS ONE 2014, 9, e87887. [CrossRef] [PubMed]

14. Wormuth, M.; Scheringer, M.; Vollenweider, M.; Hungerbühler, K. What are the sources of exposure to eight frequently used phthalic acid esters in Europeans? Risk Anal. 2006, 26, 803-824. [CrossRef] [PubMed]

15. Adeyeye, O.O.; Adekoya, A.O.; Kuyinu, Y.; Ogunleye, A. Respiratory Symptoms and Pulmonary Functions of Hairdressers in Lagos, South West Nigeria. J. Biol. Sci. 2013, 6, 32-36.

16. Barrett, J.R. The Ugly Side of Beauty Products. Environ. Health Perspect. 2005, 113, A24. [CrossRef] [PubMed]

17. Swan, S.H. Environmental phthalate exposure in relation to reproductive outcomes and other health endpoints in humans. Environ. Res. 2008, 108, 177-184. [CrossRef]

18. Leitz, J.; Kuballa, T.; Rehm, J.; Lachenmeier, D.W. Chemical analysis and risk assessment of diethyl phthalate in alcoholic beverages with special regard to unrecorded alcohol. PLoS ONE 2009, 4, e8127. [CrossRef]

19. Chang, C.J.; Cheng, S.F.; Chang, P.T.; Tsai, S.W. Indoor air quality in hairdressing salons in Taipei. Indoor Air 2018, 28, 173-180. [CrossRef] [PubMed]

20. Labrèche, F.; Forest, J.; Trottier, M.; Lalonde, M.; Simard, R. Characterization of chemical exposures in hairdressing salons. Appl. Occup. Environ. Hyg. 2003, 18, 1014-1021. [CrossRef]

21. Hollund, B.E.; Moen, B.E.; Lygre, S.H.; Florvaag, E.; Omenaas, E. Prevalence of airway symptoms among hairdressers in Bergen, Norway. Occup. Environ. Med. 2001, 58, 780-785. [CrossRef] [PubMed]

22. Ameille, J.; Pages, M.G.; Capron, F.; Proteau, J.; Rochemaure, J. Respiratory pathology induced by inhalation of hair lacquer. Rev. Pneumol. Clin. 1985, 41, 325-330. [PubMed]

23. Golińska-Zach, A.; Krawczyk-Szulc, P.; Wiszniewska, M.; Nowakowska-Świrta, E.; Świerczyńska-Machura, D.; Tymoszuk, D.; Walusiak-Skorupa, J. Sensitization to occupational allergens in hairdressing apprentices diagnosed already before entering vocational training. Med. Pracy 2016, 67, 567-575. [CrossRef] [PubMed]

24. Foss-Skiftesvik, M.H.; Winther, L.; Johnsen, C.R.; Zachariae, C.; Johansen, J.D. Incidence of skin and respiratory diseases among Danish hairdressing apprentices. Contact Dermat. 2017, 76, 160-166. [CrossRef] [PubMed]

25. Pak, V.M.; Powers, M.; Liu, J. Occupational chemical exposures among cosmetologists: Risk of reproductive disorders. Workplace Health Saf. 2013, 61, 522-528. [CrossRef] [PubMed]

26. Robinson, L.; Miller, R. The Impact of Bisphenol A and Phthalates on Allergy, Asthma, and Immune Function: A Review of Latest Findings. Curr. Environ. Health Rep. 2015, 2, 379-387. [CrossRef] [PubMed]

27. Kim, D.M.; Kang, M.Y.; Choi, S.; Park, J.; Lee, H.J.; Kim, E.A. Reproductive disorders among cosmetologists and hairdressers: A meta-analysis. Int. Arch. Occup. Environ. Health 2016, 89, 739-753. [CrossRef] [PubMed]

28. Bohadana, A.B.; Hannhart, B.; Ghezzo, H.; Teculescu, D.; Zmirou-Navier, D. Exhaled nitric oxide and spirometry in respiratory health surveillance. Occup. Med. 2011, 61, 108-114. [CrossRef]

29. Blainey, A.D.; Ollier, S.; Cundell, D.; Smith, R.E.; Davies, R.J. Occupational asthma in a hairdressing salon. Thorax 1986, 41, 42-50. [CrossRef] 
30. Schwartz, H.J.; Arnold, J.L.; Strohl, K.P. Occupational allergic rhinitis in the haircare industry: Reactions to permanent waves solutions. J. Occup. Med. 1990, 32, 473. [CrossRef]

31. Leino, T.; Tammilehto, L.; Luukkonen, R.; Nordman, H. Self-reported respiratory symptoms and diseases among hairdressers. Occup. Environ. Med. 1997, 54, 452-455. [CrossRef]

32. Mounier-Geyssant, E.; Oury, V.; Mouchot, L.; Paris, C.; Zmirou-Navier, D. Exposure of hairdressing apprentices to airborne hazardous Substances. Environ. Health 2006, 5, 23. [CrossRef] [PubMed]

33. Tossa, P.; Bohadana, A.; Demange, V.; Wild, P.; Michaely, J.P.; Hannhart, B.; Paris, C.; Zmirou-Navier, D. Early markers of airways inflammation and occupational asthma: Rationale, study design and follow-up rates among bakery, pastry and hairdressing apprentices. BMC Public Health 2009, 9, 113. [CrossRef] [PubMed]

34. Leino, T.; Tammilehto, L.; Paakkulainen, H.; Orjala, H.; Nordman, H. Occurrence of Asthma and Chronic Bronchitis Among Female Hairdressers. A questionnaire study. J. Occup. Environ. Med. 1997, 39, 534-539. [CrossRef] [PubMed]

35. Akpinar-Elci, M.; Cimrin, A.H.; Elci, O.C. Prevalence and Risk Factors of Occupational Asthma among Hairdressers in Turkey. J. Occup. Environ. Med. 2002, 44, 585-590. [CrossRef] [PubMed]

36. Brisman, J.; Albin, M.; Rylander, L.; Mikoczy, Z.; Lillienberg, L.; Höglund, A.D.; Torén, K.; Meding, B.; Diab, K.K.; Nielsen, J. The incidence of respiratory symptoms in female Swedish hairdressers. Am. J. Ind. Med. 2003, 44, 673-678. [CrossRef] [PubMed]

37. Moscato, G.; Pignatti, P.; Yacoub, M.R.; Romano, C.; Spezia, S.; Perfetti, L. Occupational asthma and occupational rhinitis in hairdressers. Chest 2005, 128, 3590-3598. [CrossRef] [PubMed]

38. Hasan, S.N.; Singh, D.; Aggarwal, T.; Agarwal, S. A study to see the effect of occupational exposure in hairdressers. JARMS 2012, 4, 350.

39. Helaskoski, E.; Suojalehto, H.; Virtanen, H.; Airaksinen, L.; Kuuliala, O.; Aalto-Korte, K.; Pesonen, M. Occupational asthma, rhinitis, and contact urticaria caused by oxidative hair dyes in hairdressers. Ann. Allergy Asthma Immunol. 2014, 112, 46-52. [CrossRef] [PubMed]

40. Kronholm Diab, K.; Jönsson, B.A.; Axmon, A.; Nielsen, J. Work-related airway symptoms, nasal reactivity and health-related quality of life in female hairdressers: A follow-up study during exposure. Int. Arch. Occup. Environ. Health 2014, 87, 61-71. [CrossRef] [PubMed]

41. Miller, M.R.; Hankinson, J.; Brusasco, V.; Burgos, F.; Casaburi, R.; Coates, A.; Crapo, R.; Enright, P.; van der Grinten, C.P.; ATS/ERS Task Force; et al. Standardisation of spirometry. Eur. Respir. J. 2005, 26, 319-338. [CrossRef] [PubMed]

42. Pilka, T.; Petrovicova, I.; Kolena, B.; Zatko, T.; Trnovec, T. Relationship between variation of seasonal temperature and extent of occupational exposure to phthalates. Environ. Sci. Pollut. Res. Int. 2015, 22, 434-440. [CrossRef] [PubMed]

43. Lind, M.L.; Albin, M.; Brisman, J.; Kronholm Diab, K.; Lillienberg, L.; Mikoczy, Z.; Nielsen, J.; Rylander, L.; Torén, K.; Meding, B. Incidence of hand eczema in female Swedish hairdressers. Occup. Environ. Med. 2007, 64, 191-195. [CrossRef] [PubMed]

44. Bradshaw, L.; Harris-Roberts, J.; Bowen, J.; Rahman, S.; Fishwick, D. Self-reported work-related symptoms in hairdressers. Occup. Med. 2011, 61, 328-334. [CrossRef] [PubMed]

45. Ferreira, A.P. An assessment of occupational health risks in female hairdressers forefront to xenobiotics. Rev. Bras. Farm. 2013, 94, 190-198.

46. Yenigün, A.; Cetemen, A.; Pektaş, E.; Karayel, E.; Özcan, N. The prevalence of respiratory and cutaneous symptoms among hairdressing apprentices in Aydin. Astma Alergy Immunol. 2010, 8, 77-87.

47. Hashemi, N.; Boskabady, M.H.; Nazari, A. Occupational Exposures and Obstructive Lung Disease: A Case-Control Study in Hairdressers. Respir. Care 2010, 55, 895-900. [PubMed]

48. Ronda, E.; Hollund, B.E.; Moen, B.E. Airborne exposure to chemical substances in hairdresser salons. Environ. Monit. Assess. 2009, 153, 83-93. [CrossRef]

49. Nemer, M.; Kristensen, P.; Nijem, K.; Bjertness, E.; Skogstad, M. Respiratory function and chemical exposures among female hairdressers in Palestine. Occup. Med. 2013, 63, 73-76. [CrossRef] [PubMed]

50. Iwatsubo, Y.; Matrat, M.; Brochard, P.; Ameille, J.; Choudat, D.; Conso, F.; Coulondre, D.; Garnier, R.; Hubert, C.; Lauzier, F.; et al. Healthy worker effect and changes in respiratory symptoms and lung function in hairdressing apprentices. Occup. Environ. Med. 2003, 60, 831-840. [CrossRef] [PubMed]

51. Baste, V.; Moen, B.E.; Riise, T.; Hollund, B.E.; Øyen, N. Infertility and spontaneous abortion among female hairdressers: The Hordaland Health Study. J. Occup. Environ. Med. 2008, 50, 1371-1377. [CrossRef] 
52. Guida, F.; Papadopoulos, A.; Menvielle, G.; Matrat, M.; Févotte, J.; Cénée, S.; Cyr, D.; Schmaus, A.; Carton, M.; Paget-Bailly, S.; et al. Risk of lung cancer and occupational history: Results of a French population-based case-control study, the ICARE study. J. Occup. Environ. Med. 2011, 53, 1068-1077. [CrossRef] [PubMed]

53. Letašiová, S.; Medved'ová, A.; Šovčíková, A.; Dušinská, M.; Volkovová, K.; Mosoiu, C.; Bartonová, A. Bladder cancer, a review of the environmental risk factors. Environ. Health 2012, 11 (Suppl. 1), S11. [CrossRef]

54. GOLD. Global Strategy for the Diagnosis, Management and Prevention of COPD. 2017. Available online: https://goldcopd.org/gold-2017-global-strategy-diagnosis-management-prevention-copd/ (accessed on 17 February 2018).

55. Chhabra, S.K. Forced vital capacity, slow vital capacity, or inspiratory vital capacity: Which is the best measure of vital capacity. J. Asthma 1998, 35, 361-365. [CrossRef] [PubMed]

56. Brusasco, V.; Pellegrino, A.; Rodarte, J.R. Vital capacities in acute and chronic airway obstruction: Dependence on flow and volume histories. Eur. Respir. J. 1997, 10, 1316-1320. [CrossRef] [PubMed]

57. O’Brien, C.; Guest, P.J.; Hill, S.L.; Stockley, R.A. Physiological and radiological characterization of patients diagnosed with chronic obstructive pulmonary disease in primary care. Thorax 2000, 55, 635-642. [CrossRef] [PubMed]

58. Slater, T.; Bradshaw, L.; Fishwick, D.; Cheng, S.; Kimbell-Dunn, M.; Erkinjuntti-Pekkanen, R.; Douwes, J.; Pearce, N. Occupational respiratory symptoms in New Zealand hairdressers. Occup. Med. 2000, 50, 586-590. [CrossRef] [PubMed]

59. Hines, C.J.; Nilsen Hopf, N.B.; Deddens, J.A.; Calafat, A.M.; Silva, M.J.; Grote, A.A.; Sammons, D.L. Urinary phthalate metabolite concentrations among workers in selected industries: A pilot biomonitoring study. Ann. Occup. Hyg. 2009, 53, 1-17. [CrossRef] [PubMed]

60. Hatch, E.E.; Nelson, J.W.; Stahlhut, R.W.; Webster, T.F. Association of endocrine disruptors and obesity: Perspectives from epidemiological studies. Int. J. Androl. 2010, 33, 324-331. [CrossRef]

61. Lind, P.M.; Roos, V.; Rönn, M.; Johansson, L.; Ahlström, H.; Kullberg, J.; Lind, L. Serum concentrations of phthalate metabolites are related to abdominal fat distribution two years later in elderly women. Environ. Health 2012, 11, 21. [CrossRef] 